\title{
Lemebel rima con San Miguel: memoria del extremo Sur
}

\author{
Gilda Luongo \\ Crítica e investigadora feminista \\ gildaluongo@gmail.com
}

Este escrito aborda la producción textual de Pedro Lemebel desde la retícula memoriaescritura, diferencia sexual/política (Ricoeur, Braidotti,). Esta trama teórica posibilita indagar sobre la localización territorial de San Miguel e interpretar sus derivas en la escritura lemebeliana. La selección textual considera aquellas crónicas que permiten rastrear cinco figuraciones memoriosas: infancia, pubertad-adolescencia, el territorio poblacional, antes/después del Golpe y, por último, personajes barriales.

Palabras clave: Crónicas de Pedro Lemebel y San Miguel, memoria/escritura, diferencia sexual/política.

The article works with the writing of Pedro Lemebel since the focus of two concepts: writing/memory and sexual/politic difference. This theoretic plot allows inquiring about the localization of San Miguel like a territory, one which opens the lemebelian writing and makes possible to understand it in a special sense. In order to interpret those senses I select some chronics which shows us five memory's figures: infancy, puberty/ adolescence, the village's territory; after/before the coup d'état, and suburbs characters.

Keywords: Writing of Pedro Lemebel and San Miguel, Memory/Writing, Sexual/ Politic Difference. 
"La amistad es siempre un acto político". Kathy Acker, Bodies of work

"La memoria es fluida y fluyente: se abre a posibilidades inesperadas o virtuales. Además es transgresora por cuanto trabaja contra los programas del sistema dominante". Rosi Braidotti, Transposiciones

"La fidelidad al pasado no es un dato es un deseo". Paul Ricoeur, La historia, la memoria, el olvido

\section{Umbral}

Escribir este texto es, en cierto sentido, una fidelidad ${ }^{1}$. Sigo el pulso del deseo (el loco afán) de ser fiel a la amistad que hemos construido juntos con Pedro Lemebel desde que le hiciera una entrevista en el año 1996 en San Miguel (Luongo, 211-225). En ese entonces yo cursaba el Postítulo en Género y Cultura, becada por la Universidad de Chile en retribución al intenso trabajo voluntario que habíamos desarrollado junto a otras mujeres para levantar el Programa que hoy es Centro de Estudios de Género y Cultura de la Facultad de Filosofía y Humanidades. En ese entonces acepté el desafío de interrogar -escritural y performáticamente- el travestismo como posible lugar deconstructivo de los binarismos de género en el marco del curso sobre Filosofía y Género que dictaba la profesora Olga Grau. Entrevistamos a tres sujetos: Claudia, travesti; Jaime Leppe, transformista y Pedro Lemebel, escritor, quien estaba empezando a circular como tal después de sus fundamentales performances como integrante de Las Yeguas del Apocalipsis (Robles 27-31, 139-140; Sutherland 129-133, 25-28).

Pedro llegó hasta mi casa materna en la comuna de San Miguel². La instantánea del primer encuentro: echados en mi cama. En ese reconocimiento

1 Lo nombro de este modo porque Pedro Lemebel funciona a manera de un territorio geopolítico chileno para esta escritura crítica: uno amigable, privilegiado en su secreto armado estético, situado por arriba de tantos otros sitios o espacios artístico-culturales de este país. He ocupado anteriormente otra figura arquitectónica para referirme a Pedro Lemebel. He dicho que es mi ático en "El pasado no pasa, pesa o Bolaño y Donoso unidos jamás serán vencidos". Allí abordo el lugar cultural complejo, denso, que ocupan las diferencias sexogénero en las casas consideradas como espacios de condensación de lo privado-íntimo en cruce con lo público en nuestra cultura chilena.

2 La Comuna de San Miguel surge en las tierras situadas al Sur de Santiago. Estas pertenecían a Ramón Subercaseaux Mercado, quien a fines del siglo XIX cedió algunas porciones de su finca para uso público. En 1896, durante el gobierno de Jorge Montt, se creó el decreto que dio origen a esta comuna que había ido creciendo en torno al Matadero. Su nombre se debe a una manda que habría hecho Gaspar Banda, uno de los españoles que acompañaron a Diego de Almagro en la Conquista de Chile. Gaspar Banda habría encomendado construir una ermita para el cumplimiento de su manda en nombre de San Miguel Arcángel. Esta fue erigida en el mismo lugar en donde se levanta en la actualidad la Iglesia San Miguel Arcángel, paradero seis de la Gran Avenida. Este territorio fue llamado la Comuna Brava en las décadas de los sesenta y setenta debido a su impulso ciudadano político de izquierda liderado por el Partido Socialista encarnado en las figuras de los hermanos Palestro Rojas. Julio, Tito y Mario Palestro Rojas fueron tres de sus renombrados alcaldes, líderes políticos, entre las décadas de los cincuenta, sesenta y setenta. Esta populosa comuna comprendía 
supimos que éramos vecinos de barrio y población, compartíamos una memoria territorial. Coincidir en un pasado localizado -haber sido habitantes infantes y jóvenes de la periferia del sur de esta ciudad- fue nuestra primera empatía. Teníamos una densa memoria en común de esos barrios pobres del entorno sanmiguelino: la antigua Panamericana con vías de tierra, el cerro de piedra, las canchas de fútbol, esos tierrales felices, las ferias libres, los bloques de la población pintados con murales de la $\mathrm{BRP}^{3}$; las/los militantes en las poblas de la Jota en los años setenta, los trabajos voluntarios, las fronteras odiosas creadas entre los habitantes barriales clasemedieros y los poblacionales: la San Miguel, Los Panificadores, Los Molineros; en tiempos de dictadura las barricadas, los cadenazos, allanamientos, operaciones rastrillo, las fiestas de toque a toque, los volanteos. Llegamos al extremo de compartir: tuvimos un amor en común. El objeto de deseo mutuo habría sido Leo Valdés, secretario político del Comité Local Chacón Corona, Regional San Miguel del Partido Comunista en los setenta. Nuestras madres fueron otro sitio poderoso que nos cobijó amorosamente. Habían tenido un rol protagónico en nuestras vidas como mujeres de férrea fortaleza para enfrentar la pobreza, ambas trabajadoras de lo doméstico en casas ajenas. Esta zona de lo amoroso materno nos hizo cómplices porque compartimos conversaciones respecto de los recovecos de la intimidad vivida en la precariedad material y las sinuosidades del feroz pulso sobreviviente de nuestras madres en ella. Descubrimos que esta identidad de clase mezclada con lo femenino normativo deconstruido, nos marcaba con fuego en nuestros corazones rojos. De este modo compartimos la mutua pasión por las diferencias culturales en cruce con la acendrada memoria de la pobreza, cuestión que nos hizo cómplices iracundos ante las diferencias de clase. Me atrevo a decir que esta zona diferencial complejizó aún más nuestra común obsesión por las diferencias de género (Luongo, Género y clase, 2011) ${ }^{4}$. Luego vino todo lo demás. Reconocernos vecinos, así, demolió todas las defensas territoriales vinculadas con lo intelectual, zona compleja en este país que solo Bolaño se ha atrevido a explorar en sus novelas de modo terrible. Toda esa frotación densa de sujetos intelectuales -clasistas, desconfiados, sospechosos, paranoicos, mezquinos, competitivos, maltratadores que suele producir ronchas en nuestras pieles-, en nosotras se desvaneció gracias a esta complicidad ético-política que ahora digo a boca llena.

De este modo, en el año 2009, en una de nuestras largas conversaciones telefónicas llenas de risotadas e ironías, surgió esta idea, la de escribir sobre sus crónicas, pero atisbando sospechosamente sobre esta localización, sobre la singularidad memoriosa de San Miguel en su escritura. Creo haberle cobrado

entonces los territorios de la actual comuna de San Joaquín y la de Pedro Aguirre Cerda hasta que en Dictadura, 1987, fue reducida en su extensión por órdenes militares.

3 Me refiero a las Brigadas Ramona Parra del Partido Comunista chileno. Estas llevaban a cabo una colorida labor muralista en las calles de las poblaciones de la ciudad de Santiago en las décadas de los sesenta y setenta. Su trabajo político-artístico-propagandístico se inició antes del triunfo de la Unidad Popular y permaneció activo durante el gobierno de Salvador Allende. Su nombre es un homenaje a la militante comunista asesinada en una manifestación en la Plaza Bulnes el 28 de enero de 1946.

4 El cruce entre estas dos diferencias ha implicado un desafío constante para los estudios de género. Las teóricas y críticas feministas no siempre alcanzamos a articular esta trama explosiva que en América Latina resulta fundamental en términos históricos, políticos y sociales. 
un "sentimiento gaucho" cuando se fue de estos barrios en dirección hacia el centro de Santiago; creo que él lo resintió y me cobró el cobro que yo le hacía. Ahora entiendo que algo insondable conectado a estos territorios nos pulsa venoso para crear, escribir, y plantearnos como sujetos posicionados, incardinados al decir de Braidotti. Esta fealdad periférica, su heterogeneidad pobre, esa suciedad, el habla fracturada, nos impulsa desde una percepción/ sensación oscura, rara, hacia la creación escritural y creo que no alcanza nunca a completarse como palabra clara, precisa, nunca monumental.

\section{Contramemoria: aion antes que chronos}

Quiero tomar la idea de cuerpos en el tiempo que me dona de modo profundo Rosi Braidotti, en su texto Transposiciones (201-277). Concibo entonces al sujeto que escribe las crónicas memoriosas en esta singularidad territorial que indago, como una entidad genealógica que posee su propia contramemoria y en ella o, más bien, a través de ella se expresan tonos de afectividad y de interconectividad. La contramemoria de esta subjetividad de la escritura se halla más conectada con aion antes que a chronos. Entendiendo a la primera como aquella temporalidad dispersa, discontinua y además cíclica. Chronos será, por el contrario, la temporalidad cruzada por lo lineal, lo fuselado, será la memoria de los bancos de datos, responde a lo centralizado del sistema y -siguiendo las elaboraciones de Deleuze- estará relacionado con el ser, con lo molar, y por ende en estrecha vinculación con lo masculino. La contramemoria, siguiendo la genealogía de aion, está armada desde los flujos del devenir activo y la toma de conciencia que ocurre desde ella, se encuentra vinculada con la memoria intensa, zigzagueante, desordenada, libre de temor, por ello es profundamente productiva ${ }^{5}$. La repetición que implica este trabajo memorioso ofrece la apertura del tiempo y se transforma en cultivo para abrir un horizonte más esperanzador y vital. La vitalidad intensa que pulsa en este afán conlleva un impulso ético-político. Braidotti lo dice del siguiente modo: "La subjetividad es un proceso que trata de crear flujos de interconexiones y de impacto mutuo. Aquí la afectividad es la palabra clave y cumple una función estructural en la visión nómada de la subjetividad, relacionada con la temporalidad íntima del sujeto, y por lo tanto, también con lo que comúnmente llamamos 'memoria'"' (Transposiciones, 214).

5 Cito dos elaboraciones de Giorgio Agamben que se relacionan con esta entrada. La primera señala: "en un fragmento de Heráclito -o sea, en los orígenes del pensamiento europeoAión, el tiempo en su carácter originario, figura como un "niño que juega a los dados" y se define la dimensión abierta por ese juego como "reino de un niño". Los etimologistas remiten la palabra aion a una raíz *ai-w, que significa "fuerza vital", y ese sería según ellos el significado de aion en sus apariciones más antiguas en los textos homéricos, antes de adquirir el significado de "médula espinal" y, finalmente, con un desplazamiento difícil de explicar, el de "duración" y "eternidad". La segunda cita: "Junto con aión, la lengua griega posee también para designar el tiempo el término chronos, que indica una duración objetiva, una cantidad mensurable y continua de tiempo. En un célebre pasaje del Timeo, Platón presenta la relación entre chrónos y aión como una relación entre copia y modelo, entre tiempo cíclico medido por el movimiento de los astros y temporalidad inmóvil y sincrónica. Lo que nos interesa no sería tanto que en el curso de una tradición todavía persistente se haya identificado aion con la eternidad y chrónos con el tiempo diacrónico, sino más bien el hecho de que nuestra cultura contenga desde su origen una escisión entre dos nociones diferentes de tiempo, correlativas y opuestas" (Grau 110-112). 
La estructura temporal de la subjetividad posibilita hablar de una memoria encarnada que puede perdurar en cruce con variaciones discontinuas, pero no por ello deja de conservar una "extraordinaria fe en sí mismo". Es una especie de "fidelidad" del sujeto que contiene, desde lo político, el repudio al individualismo tecnocapitalista y neoliberal. Ella, sin embargo, no funciona como apego o como marca de autenticidad, antes bien lo es de las relaciones y encuentros; en términos éticos se trata de estar conscientes de la capacidad que uno tiene de afectar a otros/otras y de ser una/uno a su vez, afectada/o por otras/otros. Para Giorgio Agamben aion "indica la fuerza vital en tanto que es percibida en el ser viviente como una cosa temporal, algo que 'dura'; vale decir, como la esencia temporalizante de viviente... Cuando Heráclito nos dice que aion es un niño que juega, representa entonces como juego la esencia temporalizante del ser viviente, su 'historicidad', diríamos nosotros" (Tiempo y escritura, 102-103).

En este marco temporoespacial ético-político está situado de modo intenso el sujeto de las crónicas memoriosas de Lemebel. En él, fuerzas, flujos e intensidades sostienen un umbral. Habría que señalar que no por ello la positividad que se asienta en este enfoque anula o niega las tensiones o conflictos. Interesa señalar que lo que pasa -ocurre-, es envuelto por los desplazamientos de aquello que emerge de este ejercicio memorioso que, desde el imperativo ético-estético-político, nuevamente vuelve a liarse con la zona de lo colectivo, el lazo social, que intenta prender desde los encuentros, aun en medio del dolor que pulsa en el conflicto y la tensión.

\section{Contramemoria e imaginación}

Si he dicho que la afectividad es fundamental en el ejercicio memorioso de la contramemoria, del mismo modo la imaginación será su contrapartida. Entonces afectividad e imaginación arman una trama especial para el ejercicio mnemónico. Ella posibilitará discernir las realidades contingentes de la existencia social y permitirá la labor para reelaborarlas en su amplio espectro. Desde dicha red ocurren las conexiones y los vínculos que la razón humana puede instalar para "lo humano" en su anchura. La imaginación vinculada al "hacer como si" inaugura la ambivalencia del sujeto y se sostiene como fuerza y como debilidad a la vez (Braidotti, Sujetos 32$)^{6}$. En este registro la contramemoria de las crónicas de Lemebel sería una memoria de las minorías en tanto pulsa desde el devenir de los "otros/otras" en esa sístole-diástole venosa de la imaginación y de la afectación expandiéndose y contrayéndose. Como dice Braidotti: "el esfuerzo que significa recordar o recuperar las experiencias corporizadas que son demasiado dolorosas para que la persona pueda evocarlas... es formidable. Y también contribuye a elaborar narrativas formidables" (Transposiciones 231).

\footnotetext{
6 La "filosofía del como si" que elabora Rossi Braidotti podría entenderse como la capacidad de fluir de una experiencia de sentido a otra como si ello trajera, arrastrara, unas reminiscencias o evocara otras. Sin duda esta filosofía está imbricada con el trabajo memorioso. Braidotti lo aborda en Transposiciones, específicamente en el acápite "La memoria y la imaginación" (226-235).
} 
La escritura de las crónicas de Pedro Lemebel enfocadas desde este prisma forma parte de una narrativa formidable en nuestro país y en América Latina. Por otra parte, Ricoeur presta atención especial al lugar de la memoria y la imaginación cuando propone el concepto "recuerdo-imagen". Esta hace posible la emergencia de figuras poéticas que dan lugar a la memoria feliz en cuyo seno se cobija el reconocimiento: "ies ella, es él!" (Ricoeur 634). Así, aquello que había sido olvidado es recuperado en un tono que hace posible volver a esas zonas perdidas, cubiertas al parecer por la pérdida, el dolor y el olvido (Ricoeur 74-79).

\section{Crónicas del extremo sur: figuraciones de contramemoria}

Debo comenzar diciendo que la selección de las crónicas memoriosas de San Miguel o del extremo sur, fue echa a dos voces. Pedro Lemebel me sugirió algunas y luego yo busqué otras que tuvieran desde mi lectura memoriosa ese pulso de creación desde el referente local y territorios aledaños a este. Por lo tanto hay aquí una polifonía, una complicidad coral que no hace sino dar cuenta de la afectividad y la imaginación en trama desplegada desde el ejercicio memorioso en interconexión? 7 .

Quiero decir que Pedro Lemebel inaugura la escena escritural chilena con una boca llena. Boca abierta con una lengua que no se detiene, que se suelta y se despliega para posarse, lamer, enroscarse, penetrar y libar la posibilidad de crear mundos a partir de escrituras-lecturas conectadas a referentes en movimiento; se encarama -se sube al "trapecio"- en la creación, la invención, la acción, la intervención en/con las palabras-cuerpo, signos, significantes, sonoridades y materialidades densas, llenas de ecos y resonancias múltiples siempre. Uso la imagen del trapecio tomada de la crónica "Ese afiebrado sol de la niñez". En ella el narrador nombra su deseo de haber sido trapecista y afirma: "nunca fui trapecista". La imagen del trapecio prolifera en varios textos. Afirmo que Pedro Lemebel es el gran trapecista de la escritura que al fin logró realizar su sueño de infante pobre, suspendido entre signos y vaivenes múltiples. El sistema literario en el que circula su praxis escritural, el Chile social y cultural, vendría a ser el gran circo (¿pobre?), ese que el escritor tan bellamente anheló en su infancia de niño raro y pobre.

En este mapa (des)plegado de su escritura, he vuelto a gozar la lectura de las crónicas, y vuelvo a hallar esa fuerza vital estética que Lemebel nos ha donado tan bella e intensamente. Su escritura es de una poética intensidad. En mi lectura he buscado, obsesiva-alucinada, conectar memoria, escritura, diferencia sexual-política, ello me ha llevado a nombrar cinco figuraciones que aparecen como "estrella guía" (Ricoeur 634) en los escritos de Pedro Lemebel relativos a su nostálgica localidad: San Miguel. Estas son: infancia,

7 Las siguientes son las crónicas elegidas para esta labor: "Zanjón de la aguada", "Ese afiebrado sol de la niñez", "Las manitos arañadas del liceo industrial", "La vi parada allí", "Son quince, son veinte, son", "Tonada pascuera", Mamá pistola", "La esquina es mi corazón o los new quids del bloque", "Noche quiltra", "Camilo Escalona", "Un letrero soviet en el techo del bloque", "Flores plebeyas", "Un domingo de Feria libre", "El hospital del trabajador", "Los prisioneros", "Blokes". Remito a la bibliografía. 
pubertad-adolescencia, el territorio poblacional, antes/después del golpe y personajes barriales.

\section{Memoria/infancia/pobreza: casa/calle}

En este sitio-signo la silueta del niño pobre se halla entrecruzada por la casa, la madre, la calle. Esos ojos infantes miran curiosos a través de los del narrador, sujeto instalado esquiva y raramente en el trapecio de la escritura, una escena. Olga Grau, filósofa y feminista chilena, señala: "Si infancia (infantia) es lo que no se habla, lo que no se deja hablar, o escribir, podemos entenderla también como lo que se resiste a darse completamente y de modo directo, lo in-donado y también lo perdido, que burla cualquier deseo de saber absoluto. Puede devenir en lugar de fantasías, de recurrencia a lo imaginario, de posible invención de un origen de nosotros mismos, de la constitución de un relato primario respecto de nuestra subjetividad" (Grau 177). Digo con toda amplitud la palabra escena porque así quiere Lemebel que se lea esta "Crónica en tres actos" (Zanjón 13-23). Su teatralización contiene la bella crueldad de cuerpos en escena, materialidades plenas de gestos, luces, sombras y un multicolor vestuario. De este modo emerge la diferencia que constituye la infancia en la cultura chilena. Esta comienza a llenarse con otra huella más indeleble aún: la diferencia de clase, la pobreza de la gran patria. Ambas diferencias -en coexistencia-comenzarán a rozarse, de modo extremo, con una tercera, la sexual, al dibujar a este niño pobre como "raro". Pienso, conmovida, en la insondable zona mixturada de tres agudas puntas culturales en la poética de la infancia de Lemebel. Cada una remitiendo a la otra en pliegues. No hallo en mi memoria lectora precedente alguno que provoque un eco similar a partir de esta creación escritural, armado múltiple. Por ello es tan potente el gesto de este escritor que nombra tres plegamientos diferenciales complejos reunidos en la infancia y con este gesto-movimiento nos deja batallando entre emociones y reflexiones que surgen de la provocación de su trabajo memorioso intenso.

La voz del narrador-cronista se vuelve al lugar del nacimiento: el Zanjón de la Aguada. La escena pareciera ser el callejón cercano al cauce de las aguas servidas: el canal. Nacer en este "piojal de pobreza" cercano al fluir del agua sucia, hedionda, de oscuro color marrón, pareciera ser el fondo que dejará en el autor-narrador una inevitable tendencia al devenir, a la transformación y al movimiento constante de esas aguas barrosas en su color, olor y textura (Zanjón 13) ${ }^{8}$. La vuelta memoriosa al territorio, al tierral, inaugura a su vez la(s) casa (s), que se multiplica(n) a partir de las palabras que usa el narrador para asediarla(s): ranchales, casuchas, callampas, lodazal. Aquella construcción es levantada a duras penas por la figura de una mujer, abuela o madre, entre remiendos de palos, fonolas mientras el niño que la ve hacer mira, siente y piensa ${ }^{9}$. Esa arquitectónica piñufla al fin tendrá puertas

\footnotetext{
8 Resulta fundamental en el relato "Zanjón de la aguada (Crónica en tres actos)" el cruce entre infancia/madre/territorio de pobreza, bellas imágenes de esta tríada se hallan desplegadas en esta puntual escritura.

9 En la escritura crítica suscitada por el filme Vasnia de Carolina Adriazola, trabajo la figura de la "casa-mediagua" como arquitectónica material urdida precariamente a la construcción feble de la subjetividad femenina. El filme despliega la figura de la mujer pobre que intenta
} 
y ventanas: un cobijo. Pero junto a este lugar uterino permanecería atado al cuerpo infantil el otro sitio, el otro lugar: la intemperie callejera poblacional en su desborde y amplitud. Este cruce territorial posibilita tatuar el recuerdo, dice, en "la tiritona mañana infantil" (Zanjón 15). Ello es posible porque: "aprendí todo lo bueno y supe de todo lo malo" (Zanjón 15), así callejeramente prolífico podrá pintar de colores su primera crónica. Tal vez estas pinceladas iniciales - de los primeros años-, teñirán el registro tonal de la mayoría de sus crónicas. Resulta trabajoso definir este registro. Confieso que desde el latido poético lo asocié primariamente al poemario de Vallejo, Trilce. Sin embargo, algo perturbaba llamar vallejianamente al pulso escritural de Pedro Lemebel como Triste y Du/ce. Llegué a pensar en otra palabra, armada de modo semejante al fragmento fónico que constituye el nombre del poemario inigualable de Vallejo. El resultado vino a ser Trisa, que arma la conjunción más certera: Tristeza y Risa. Combinatoria sinuosa que hace explotar la gestualidad del rostro en una faz múltiple. Movilidad musculosa de gestos que van desde el rictus de labios y ojos hacia abajo -lo que llamamos "carita triste" o "boquita de pena"-, hasta la boca desplegada excesivamente hacia arriba, abierta, explotando en la risotada a flor de lengua y labios. Entre estas emociones bellamente extremas Lemebel ajusta, gira su foco difuso, ancho, dilatado, superabundante -a veces impreciso, vago, borroso- hacia la infancia de ese niño raro y pobre. Nos lanza imágenes múltiples sin ningún pudor. Impudicia. Esa palabra que enamora porque se halla falta de recato y por ende expulsa cualquier remilgo afectado. Entonces veo en la pantalla de la escritura al pendejo pobre deambular ${ }^{10}$ y digo: ies él! Lo sorprendo beber curioso el agua-lodo de las aguas servidas del zanjón para conocer el sabor de su origen; lo encuentro milagrosamente embarazado de un pirigüín, parturiento dando a luz un niño-renacuajo; lo miro pescando peces dorados en el Parque Cousiño (re-nombrado Parque O'Higgins en los setenta) para ganarse la vida; lo hallo pintando tarjetas de Pascua para luego pedir unas monedas por ellas, lo atisbo robar pequeñeces cuando hace el aseo en alguna casa rica del espacio clase-mediero del Parque El Llano Subercaseaux, en la Gran Avenida -esa calle que ahora no es ni Gran ni Avenida-; lo miro sacar ciruelas verdes de los árboles de la calle y de las casonas; lo observo gozosa cuando se baña en las aguas mugrientas de las piletas del Parque Subercaseax; lo envidio mirándolo jugar al tombo, al corre que te pillo, aprovechándose para manosearse con otros chiquillos; lo descubro revolcándose en los pastos y rodar entrepiernas afiebradas de niños; lo sigo al colgarse de camiones en su parte trasera sin que los conductores se den cuenta y lanzarse del vehículo cuando la velocidad ha aumentado para sentir ese vértigo fatal en el cuerpo infante bamboleante, descentrado ("Ese afiebrado sol"); lo miro enamorado eterno frente a la madre intentando entregarle una tarjeta hecha por él en su día, cautivado por esa figura enorme, una hipérbole gigante que lo copa todo (Serenata 25); lo reconozco en la escuela (esa cárcel) avergonzado, temeroso de las risas de sus pares y de los profesores, pajarillo asustado; lo sorprendo haciendo la cimarra en el cerro Santa Lucía, trazando líneas,

habitar la casa-miseria, con todo lo teratológico que ello implica: devenir sujeto femenino, desgarrada-madre-pobre en los cerros de Valparaíso. Ver: Luongo, Gilda. "Zona de desastre. La casa-mediagua de Vasnia Moncada".

10 Todas estas "visiones" corresponden a las narraciones de las crónicas seleccionadas para este trabajo y las relativas, según mi lectura, a memoria e infancia. 
dibujando; lo miro descubriendo dichoso la música de los Beatles en una feria de diversiones; lo miro gozoso metiendo la mano en el bolsillo de ese púber de "La vi parada allí" (Serenata 29-31) y sentir -tal vez por primera vez- la tumescencia eréctil y el flujo tibio del semen juvenil; lo observo en una Pascua pidiéndole de regalo un libro a su madre, contraviniendo el deseo de la propia madre-niña que anhelaba para él su propio regalo incumplido (Serenata 18); lo miro mirar las masturbaciones colectivas de muchachos, sorprendido ante tamaños penes; lo distingo, único, en el circo imaginado soñando equilibrarse en el anhelado trapecio ("Ese afiebrado sol").

\section{Memoria púber/adolescente y diferencia sexual: escuela/calle}

La imagen del cuerpo púber, juvenil, anómalo en su masculinidad; flacuchento, frágil, aparece cubierto por la violencia masculina rememorada en los relatos que selecciono para esta figuración. La diferencia sexual abyecta transita entre la escuela y la calle, expuesta al escarnio, al abuso que emerge desde la construcción cultural de género hegemónica expandida y proliferante como si fuera una maraña de maleza seca en el tierral. La figura púber -que va dejando ir su infancia para elevarse a la categoría de adolescente- padece las instituciones formativas machas que no dejan territorio libre o disponible para que la habite ningún diferente sexual. Llamo a esto una invasión, ocupación de espacios normativos heterosexuales cerrados unos y abiertos otros en esta localidad periférica. La escuela-cárcel -Liceo Industrial- ofrece un espacio de rememoración del doble padecimiento: la pobreza no deja lugar a otra opción, será este futuro o no será ninguno. En principio, cubren la escena escolar imágenes de herramientas que hieren las manitos juveniles, estas resultan "arañadas" debido a la colisión entre los dedos y las garras de los fierros, las puntas, los taladros, las escofinas. Toda una arquitectónica fálica que se erige para calzar en los ajustes maquinarios de la producción masculina, técnica y obrera de la triste modernidad tercermundista. El joven púber, que adolece, soporta estos instrumentos. Pero no padecerá por mucho tiempo las otras heridas: miradas y descalificaciones brutales del profesor de biología: Freddy Soto, un mezquino engranaje más de la institución escolar, figura monstruosa que en su violencia parece pretender expulsar de sí todo deseo homosexual. La venganza emerge dulce, pero en la complicidad de una masculinidad feminizada, fracturada por la diferencia de clase del profesor de Historia en complicidad con la rareza del púber. Ambos escarnios merecían justicia. Ella tenía que nacer de otro profesor porque el frágil púber solo podía intentar un giro, un paso de baile, una estrategia danzarina que tramara la coreografía entre hombres haciendo gala en la escena de su masculinidad herida ("Las manitos arañadas"). Otro relato-crónica resulta más cruento en su violencia y en la exposición del púber. El cuerpo errado/errático juvenil nuevamente entra en la escena memoriosa: "Nunca fui guapa, pero era joven y tierna, lo que equivale siempre a un plus de belleza" (Serenata 41). Esa turgencia joven es presa para otros machos frescos que andan a la caza de alguna rareza que sacie su homoerótica reprimida. En esta escena reverbera el eco del famoso personaje Pancho Vega deseando con odio al frágil travesti La Manuela, en la hermosa novela El lugar sin límite de José Donoso. Solo que en esta crónica ocurre otro final, uno que rompe la brutal radicalidad de esa violencia deseante del sexo-muerte del otro. El miedo desatado en el 
adolescente en la crónica de Lemebel llega a un clímax tal que lo convierte hermosamente en placidez, en un desapego budista de la escena de horror que logra conmover a uno de los agresores paralizando así su violencia. Surge de este modo una fractura en el deseo, una interrupción, como si el hecho de dejar ir al miedo detuviera el deseo violento, animal de los supuestos machos. La huida, la fuga de las garras machas es posible gracias a esa calma, a ese desapego de la escena de lo ominoso masculino. Un ángel no habría sido absuelto del modo en que lo fue el violentado adolescente raro.

\section{Memoria del territorio poblacional: pobre arquitectónica heterogénea}

El territorio poblacional en las crónicas elegidas para esta figuración se dona generoso, como un protagonista inevitable. La calle, una vez más, se ofrece en ese pulso que la ubica como límite, frontera amplia de bloques, edificios, plazas, jardines, escaleras, portones, rejas, balcones, ferias libres, esquinas. Esta apertura sinuosa en su vaivén acoge a los y las habitantes de este margen heterogéneo y aparecen disparados -en la escritura lemebeliana- como balas a quemarropa.

En esta arquitectónica memoriosa la invasión de la publicidad neoliberal es escenificada irónicamente para evidenciar la distancia desde la que sus habitantes la acogen, sobre todo los más populares. Los otros -clasemedieros arribistas- le abren sus puertas, ventanas y muros de los bloques. Creen ganar algo, ilusionados. Los otros creen perder y se revuelven un tanto envidiosos en su abigarrada heterogeneidad de colores y formas ornamentales; todas múltiples, posando de un barroquismo turbio, piñufla, terco, empeñado en persistir habitando así ("Un letrero soviet" 135-138). Los jardines de casitas y departamentos, por otra parte, se transforman en zonas caras para el ojo memorioso que recupera la flora frágil y su porfía. Sostenida en bacinicas, ollas, jarrones rotos se despliegan orgullosos de su tacaño colgante verdor. A los ojos del narrador-cronista este, sin embargo, es más atractivo que el otro, el de zonas adineradas en el que la competencia por el mejor verde, el más sofisticado, el más brillante ciega ante su reconocimiento ("Flores plebeyas" 165-166). El espacio continúa abriéndose al rememorar una hilera múltiple, risueña en voces y modos de decir: la feria libre del domingo. La calle que la acoge, Tristán Matta -nadie sabe quién fue este señor y a nadie le interesa-, cubre desde la Panamericana hasta el fin de la población San Miguel, antes de llegar a Gran Avenida, con puestos disímiles, de colores y olores múltiples. Caseritos -caseritas- es un oasis en medio del tráfago dominguero. La conversación brota fácil, el chiste, la talla, esa anécdota, la pregunta y la respuesta ágil, tan chilena en su modo de decir picante a veces rudo y sinuosamente agresivo, las quejas por la carestía o porque han manoseado la mercadería con abuso; el regateo, los coqueteos entre sus habitantes, sus historias ("Un domingo de feria libre" 206-207). Todo ello conforma un mapa abigarrado de múltiples entradas y salidas. Otra visión de estas arquitecturas barriales es la esquina. Ángulo denso que condensa energías, deseos y extravíos de jóvenes marginales. La escritura lemebeliana rememora otro tiempo, uno que ofrecía estos puntos callejeros como cuna de intercambios corporales, voces, imágenes, roces y fricciones, transacciones de juegos y materias de todo tipo entre habitantes 
jóvenes; los pendex. "La esquina de la pobla es un corazón donde apoyar la oreja" (La esquina 15) en el que se puede escuchar su pulso musical. La esquina ha dejado de ser tal. Por ello el memorioso texto de Lemebel cobra una densa niebla fantasmal. Sin embargo, los jóvenes aún se arriesgan en desplazamientos callejeros fugaces. Antes, la esquina parecía detener lo móvil y fijarlo allí a la vez que lo ampliaba como una lente feroz que favorecía la anticipación de una instantánea terrible, vaticinando aquella fatalidad que rondaba a esos jóvenes de poblaciones marginales en fatales tiempos de dictadura y neoliberalismo en ciernes. La última crónica que selecciono para este apartado, una de las más bellas según mi opinión, "Noche quiltra", escenifica un espacio-tiempo singular: Departamental y la escalera del bloque en la madrugada de un sábado. El narrador-cronista relata su periplo para llegar desde el centro fiestero, Bellavista, hasta el paradero doce por Panamericana. La periferia Sur lo acoge en el frío y áspero concreto. En ella los pendex poblacionales cuelgan de la escalera como prendas de ropa sucia, a medio lavar y lo detendrán para un último trago necesario. Todo pasa como siempre. Hasta el apagón del narrador-cronista, saturación del jolgorio, ocurre como algo esperado. Sin embargo, una sorpresa se cuela en esta repetición: despertar acompasado por el pelaje del Cholo, un perro, el infaltable en la pobla, ese que en su animal humanidad lo ha cobijado con su calor aplacando el tacto del cemento frío de la madrugada solitaria, a unos pasos de su puerta. La gratitud del narrador-cronista no se hace esperar, le devuelve un buen consuelo masturbador con su mano generosa que sabe ser maestra en la caricia: "Y así se fue meneándome la cola caninamente agradecido, y yo también le dije adiós con la mano espumosa de su semen cuando en el cielo una costra de zoofílica humanidad amenazaba con clarear" ("Noche quiltra" 163).

\section{Memoria telescopio: antes/después del golpe}

Un vacío profundo emerge de esta obra gruesa memoriosa. Aún duele como pérdida. Por ello pulsa el deber de memoria (Ricoeur 110-120) en estas crónicas $^{11}$ (Luongo, Perladas, 2011). Desear poner el lente de aumento en "El hospital del trabajador (o el sueño quebrado del doctor Allende)" implica saldar la deuda y hacer justicia a un anhelo: el proyecto de la UP (Unidad Popular), ese que fue nuestro, encarnado en la figura de Salvador Allende, como si contuviera a esa masa grávida. El pasado que no pasa, pesa. Hacer ver, hacerse cargo de la función ostensiva que acarrea el trabajo de memoria, anular la ausencia y la distancia y poner ante los ojos: recuerdo-imagen. Eso es. No es solo el hospital inacabado en su construcción, esa mole interminable de ladrillo, obra gruesa, "gran calavera estancada en la zona Sur de Santiago" (De perlas 210), esa que aún veo a diario desde mi ventana, en el tercer piso.

\footnotetext{
11 En "Perladas cicatrices: signos memoriosos en Pedro Lemebel", texto de presentación a la reedición de De perlas y cicatrices, Feria del Libro el año 2010, me detengo en el trabajo de memoria que cubre esta escritura y afirmo que es una corriente sinuosa que se mueve en el péndulo atracción/repulsión. Allí señalo: "La mayoría de las crónicas nos arroja el gesto escritural de atracción/repulsión. Atracción por lo que yace en el fondo de cada referente memorioso asediado, dado que tiene 'algo', un incierto aire-vuelo de perla cultivada, sin embargo -en un giro feroz inscrito en los tonos perpetuos de las heridas chilenas-, emerge el tajo que devendrá cicatriz" (Luongo, "Perladas cicatrices").
} 
Rememoro "antes del Golpe" en este sector Sur: sueños, ideales, trabajos voluntarios, futuro creador desbordante, manos laboriosas en plazas llenas de anhelos, transformación de la matriz cultural patronal-colonial chilena, traslados en micros de la ETC hacia los puntos de las masivas marchas, los cordones industriales de la Comuna Brava de San Miguel, las plenarias en zonas del paradero uno de la Gran Avenida, en el paradero doce -Departamental-, las entregas de carnet del partido, su jolgorio, nuestra camisa amaranto. El sueño "sin límites del doctor Allende no midió su cariño" (De perlas 210). Porque entonces no se trataba de medir, ni acaparar, o mezquinar, NO de ganar dinero. Éramos generosos en nuestro sueño de pobres desbordados. Luego, "después del Golpe" "historias de detenidos y fusilados navegaron por los ecos nocturnos de matracas y balazos en sus enormes naves vacías" (De perlas 211). El narrador-cronista planea su ojo telescópico sobre este terreno donándonos instantáneas sobre los modos ocupas del Hospital en ruinas. Muestra los vaivenes del Chile de los ochenta, los noventa. Será lugar que aprovisione -con sus restos- de material de construcción a vecinos que esperan completar sus casitas a medio terminar; territorio de barricadas en la resistencia a la dictadura, sitio de hospedaje para vagabundos, motel parejero de marginales; sitio de arte para algunos artistas; terreno para reportajes sobre la UP, zona de hallazgo de inevitables femicidios: la violación y muerte de Viviana Lavados; espacio de imaginería y penar satánico; zona de acogida para jóvenes pintores de graffiti, territorio de ocurrencias para municipios que anhelan transformar o demoler el lugar. Pareciera que este narrador al usar el espejo cóncavo telescópico para su relato re-construyera en su metafórica-metonímica a Chile entero en el paso pesado del pasado que no pasa, escritura memoriosa, inacabable del "Hospital del Trabajador".

En "Blokes", cuento que aparece fechado por el autor en el verano del año 1984, la sexualidad del narrador púber construye al sujeto de su deseo, otro joven adolescente a partir de "pedazos, fragmentos de memoria" desde los bloques ( $\mathrm{s} / \mathrm{p})$. En este relato se trama un trío: la represión en dictadura, la sexualidad juvenil secreta y el tono de país aplastado, sangrante. Todo ello condensado en cada "nudo de piezas" (s/p) como se nombra a los departamentos de los bloques poblacionales. Vigilancia, clandestinidad, opresión, miedo, sometimiento, locura femenina, parecieran pulsar en la expresión del deseo sexual juvenil en tiempos del horror dictatorial. Este parece colarse entre las palabras del relato como queriendo pasar inadvertido entre erecciones, poses de cuerpos y fluidos, pero está ahí, al acecho desplegándose como lo ominoso inevitable en la presencia de botas, vestimenta militar, allanamientos, culatazos. Se hace presente en el gesto más inocente del desborde sexual-amoroso del fantaseador-voyeur púber homosexual. Una homerótica culpable cierra el cuento porque en estos contextos todo puede ser fatal y cualquier gesto deseante puede convertirse en traidor.

\section{Memoria de personajes barriales: periferia-centro/centro-periferia}

"Los prisioneros" toma la figura triádica del grupo musical rockero del Chile de los ochenta: Jorge González, Miguel Tapia y Claudio Narea, sanmiguelinos de origen, llegarán a ser un punto musical central en contextos de la dictadura militar. Sus canciones retomaban temáticas que devolvían los setenta en su esplendor futuro abortado para este país. También denunciaban 
el estado de aplastamiento de los y las jóvenes en contextos de emergencia neoliberal. Sus letras seductoras - para quienes esperábamos votar al dictador- eran coreadas por niños, niñas, jóvenes y adultos. El tono del narrador cronista se vuelve melancólico. Asienta una nueva pérdida: los prisioneros son tragados por la devoradora, esa maraña neoliberal exitista. Sin embargo, pareciera que uno de ellos, Claudio Narea, permanece próximo al vínculo afectivo -conexión con el territorio memorioso-, fiel a su mapa clasemediero pobretón. Memoria desdichada, podría ser el nombre que esta escritura arma, una que no alcanza a avizorar la estrella guía, ese "reconocimiento" porque no fulmina la pérdida en el re-crear la imagen-recuerdo feliz. El relato se halla traspasado por el aborto de un proyecto que no era solo musical, era también ético-político en su proyección.

En la crónica "Camilo Escalona", el tono memorioso se vuelve ácido, vengador del olvido que nace del personaje famoso. Uno que habría emergido de estas barriadas del Sur pobre y juguetón. Este texto se encarama a la visión de un territorio de infancia en el que coexistían las diferencias entre infantes y jóvenes en su armado heterogéneo: las poblaciones crecían en esa tonalidad mezclada de mapuche-mestizo blanco-ennegrecido. Los ojos claros del personaje famoso y central, futuro diputado de la Nación, funcionan en el texto a manera de una anticipación de la huida de Escalona de estos lares periféricos, de su proximidad mentirosa que no trepida en olvidar para ocupar lugares más centrales. Se abriría paso a través de la FESES, sería dirigente en los años setenta de esa organización estudiantil. Escalaría en un partido político y, para el Golpe, saldría corriendo al exilio con "el acuario de sus ojos" a cuestas (De perlas 39). Nunca vería al narrador-cronista, ese sujeto raro que estuvo a su lado en el mismo territorio poblacional, no lo reconocería porque tal vez "nunca fuiste de los nuestros... ¿Cómo me ibas a ver desde las alturas del Marxismo Leninista?" (De perlas 40). Por mientras, los restos de la periferia siguen multiplicándose, cuestión que a Escalona no le importaría porque eso formaba parte de un pasado piojento con paisajes poco honorables: "los potreros de San Miguel, cuando todos los sueños infantiles cabían en unos ligeros zapatos rotos" (De perlas 41).

\section{A modo de cierre}

Descubro a Pedro Lemebel memorioso, lo descubro así en el "trapecio" de su escritura a la búsqueda del (des)equilibrio y me contento de saberlo al fin en su pleno sueño y le digo: -siempre fuiste y has sido trapecista, Pedro, en tu pintura, en tus dibujos, en tus performances, en la búsqueda incansable de la calle, de la justicia social, de amigos y amigas, del amor escamoteado "donde tuve un sueño de embriagado trapecista, sin red..." (Adiós mariquita 158); en el armado de tus casas, en ganarte la vida, en tus salidas y entradas a este país, en la búsqueda incansable de la madre $\tan . . . \tan . . . \tan$, todo. Atesoras el mejor trapecio: tu escritura, en ella imaginación, memoria y afectividad logran hacerte volar por los aires junto a los pájaros de tus precoces manos. Esta escritura-memoria mía, es uno de los tantos focos con que soñabas -sueñas-, y tú estás (estarás) en el centro de la pista iluminado por ella. 


\section{Obras citadas}

Braidotti, Rosi. Transposiciones. Sobre una ética nómada. Barcelona: Gedisa, 2009.

Sujetos nómades. Buenos Aires: Paidós, 2000.

Grau, Olga. Tiempo y escritura. El Diario y los escritos autobiográficos de Luis Oyarzún. Santiago: Editorial Universitaria, 2008.

Lemebel, Pedro. "Zanjón de la Aguada". Zanjón de la Aguada. Santiago: Planeta, 2003: 13-23.

"Ese afiebrado sol de la niñez". <http://www.lanacion.cl/noticias/site/ artic/20081206/pags/20081206210919.html>

"Las manitos arañadas del liceo industrial". < http://www.lanacion.cl/ noticias/site/artic/20090307/pags/20090307184706.html>

"La vi parada allí". Serenata cafiola. Santiago: Planeta, 2008: 29-31.

"Son quince, son veinte, son..". Serenata cafiola. 41-45.

"Tonada pascuera", en Serenata cafiola. 17-19.

"Mamá pistola", en Serenata cafiola. 25-27.

"La esquina es mi corazón o Los new quids del bloque". La esquina es mi corazón, Santiago: Cuarto Propio, 1995: 15-18.

"Noche quiltra". Adiós Mariquita linda. Santiago: Random House Monadori, 2004: 161-163.

"Carta 4". Adiós Mariquita linda. Santiago: Random House Monadori, 2004:157-158.

"Camilo Escalona". De perlas y cicatrices. Santiago: LOM, 1998: 39-41.

"Un letrero soviet en el techo del bloque". De perlas y cicatrices. 135-137.

"Flores plebeyas", en De perlas y cicatrices.165-166.

"Un domingo de Feria Libre". De perlas y cicatrices. 206-207.

"El hospital del trabajador". De perlas y cicatrices. 210-212.

"Los prisioneros". De perlas y cicatrices.126-128.

"Blokes". Fotocopia, s/r.

Luongo, Gilda. "El pasado no pasa, pesa, o Bolaño y Donoso unidos, jamás serán vencidos (Chile: antes-después de la dictadura)". < http:// nuevomundo.revues.org/index30462.html\#representaciones-urbanase-identidades-femeninas-en-america-latina-de-fines-del-siglo-xix-aprincipios-del-siglo-xxi>2009, París, Francia.

"Género y clase: una suave trama explosiva". 2011 [documento en línea]. Disponible en: <http://bibliotecafragmentada.org/?p=189>Formato pdf. "Zona de desastre. La casa-mediagua de Vasnia Moncada". 2009. Dossier "Nombres del pueblo. Cine y política". Disponible en: <http:// www.lafuga.cl/zona-de-demolicion/369>

"La teatralización de Pedro Lemebel: el voyeur invertido sobre sí mismo". Anuario del Programa de Género y Cultura en América Latina. Facultad de Filosofía y Humanidades, Universidad de Chile, 1996: 211-225.

"Perladas cicatrices: signos memoriosos en Pedro Lemebel". 2011. Disponible en: <http://bibliotecafragmentada.org/?p=189>Formato pdf.

Ricoeur, Paul, La memoria, la historia, el olvido. Buenos Aires: Fondo de Cultura Económica, 2010.

Robles, Víctor Hugo. Bandera Hueca Robles. Santiago: Arcis-Cuarto Propio, 2008.

Sutherland, Juan Pablo. Nación Marica. Santiago: Ripio Ediciones, 2009. 